\title{
The fossil record of the short-faced bears (Ursidae, Tremarctinae) from Venezuela. Systematic, biogeographic, and paleoecological implications
}

\author{
Leopoldo H. Soibelzon, La Plata and Ascanio D. Rincón, Caracas
}

With 4 figures and 8 tables

SolBelzon, L. H. \& Rincón, A. D. (2007): The fossil record of the short-faced bears (Ursidae, Tremarctinae) from Venezuela. Systematic, biogeographic, and paleoecological implications. - N. Jb. Geol. Paläont. Abh., 244: 287-298; Stuttgart.

\begin{abstract}
The first record of a Tremarctinae bear in Venezuela was made by RoYo y GómEZ in 1960. Since then, three new specimens from two localities have been collected but not reported. The purpose of this contribution is to discuss the taxonomy, biostratigraphy, and biogeographic implications of these records. The bear genera included in the subfamily Tremarctinae are distributed exclusively in America. In South America only one fossil genus is recorded, Arctotherium, comprising five species: A. angustidens, restricted to the Ensenadan (early - middle Pleistocene) of Argentina and Bolivia; A. vetustum, recorded only in the Bonaerian (middle Pleistocene) of Brazil and Argentina; two Bonaerian and Lujanian (middle Pleistocene - early Holocene) species, $A$. bonariense (recorded only in Argentina), and A. tarijense (occurring in Argentina, Bolivia, Uruguay and Chile); and $A$. wingei, recorded with certainty only in the Lujanian (late Pleistocene - early Holocene). After the present study we conclude that (1) A. wingei is the only species recorded in Venezuela, and (2) all known specimens have Lujanian provenance. Outside Venezuela, this species is recorded from Bolivia and Brazil but without precise stratigraphic data. Although A. wingei is one of the most plesiomorphic Arctotherium species, it has not been recorded in sediments older than late Pleistocene. This could be interpreted as species preference for low latitude tropical or subtropical environments, which are poorly represented in early Pleistocene continental sediments.
\end{abstract}

Key words: Ursidae, Tremarctinae, Arctotherium wingei, South America, Muaco, Guácharo Cave, Venezuela, Pleistocene.

\section{Introduction}

The bear genera that constitute the subfamily Tremarctinae (Carnivora: Ursidae) are distributed exclusively in America. Of these, (1) Plionarctos is recorded from late Miocene to early Pliocene of North America with two species, $P$. edensis and $P$. harroldorum; (2) Arctodus contains two North American late Pliocene - Pleistocene species, A. pristinus and A. simus; (3) Arctotherium comprises five South
American species: $A$. angustidens, restricted to the Ensenadan (early - middle Pleistocene), A. vetustum, recorded only in the Bonaerian (middle Pleistocene), two Bonaerian-Lujanian (middle Pleistocene - early Holocene) species, A. bonariense, and A. tarijense (SoIBELzon 2004), and $A$. wingei, recorded with certainty in the Upper Pleistocene only (as established in this paper); and (4) Tremarctos with two species, T. floridanus from the late Pliocene and Pleistocene of North America, and the only living tremarctine, $T$. 


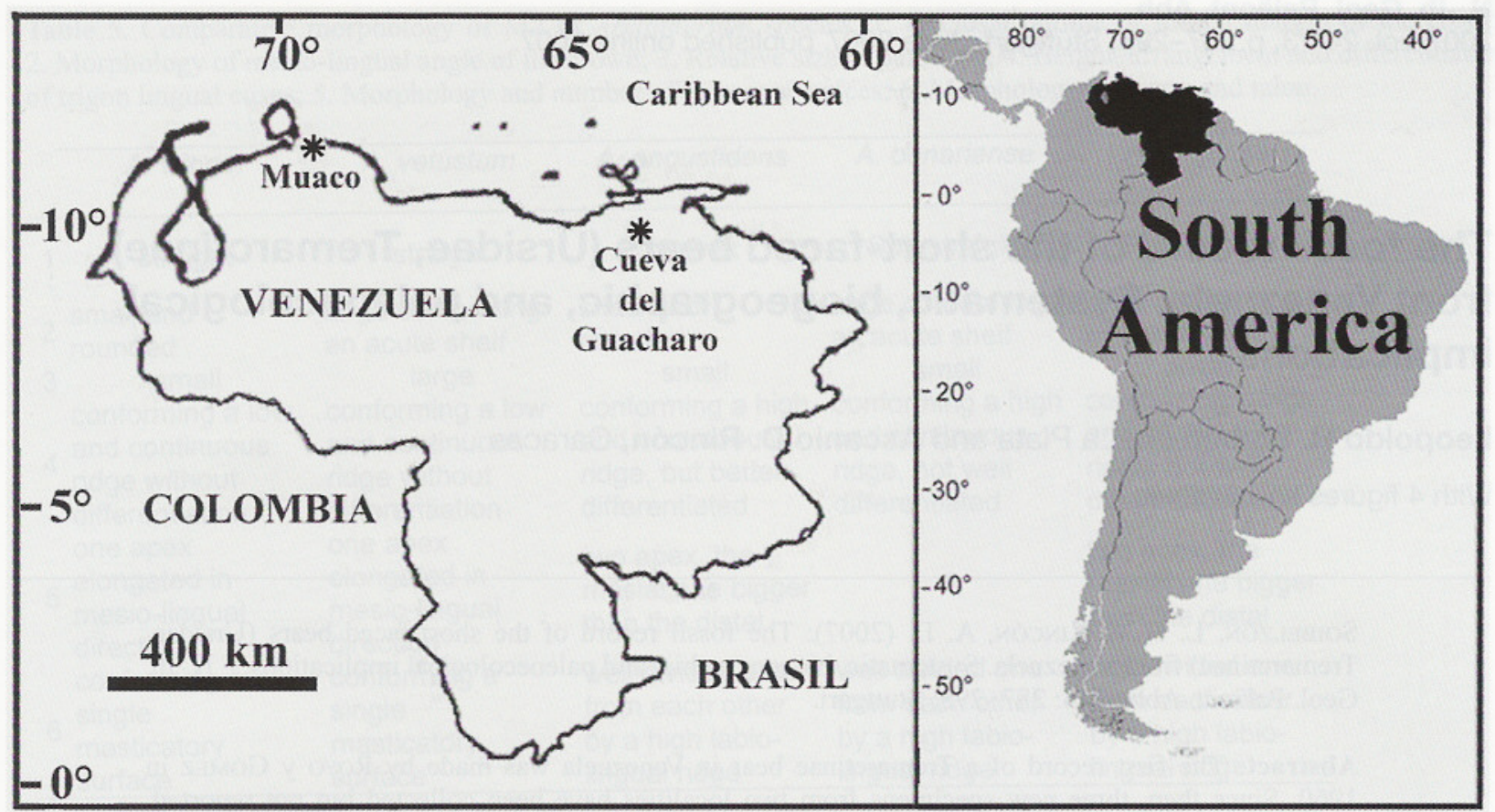

Fig. 1. Map of Venezuela depicting the localities "Cueva del Guácharo" (Monagas state, Venezuela) and Muaco (Falcón State, Venezuela).

ornatus from South America, which has not been recorded as a fossil thus far. The Tremarctinae are a monophyletic group, with Plionarctos and Tremarctos as basal genera representing the sister group of the short-faced bear clade formed by Arctodus and Arctotherium, the most derived genus of the subfamily (SoIBELzon $2002 \mathrm{a}$, b).

The first record of Tremarctinae in Venezuela was made by Royo y Gómez (1960) in Muaco, Falcón state (Fig. 1); this author identified the specimens VF-405 and 406 (Fig. 2a) as Arctotherium cf. brasiliense, but they did not provide a description. Later, BoCQUENTIN-VILLANUEVA (1979) assigned these specimens to Arctodus brasiliensis. CASAMIQUELA (1979) cited Pararctotherium for the late Pleistocene of Taima-Taima, Falcón state. In 1994, LiNARES reported the presence of $A$. brasiliensis in Cueva del Guácharo (Fig. 1) but he never published any figures, descriptions or collection numbers of the specimens he mentioned. Recently AguILERA SOCORRo (2006) referred the short-faced bears from Taima-Taima to Arctotherium brasiliense.

The fossil record of $A$. wingei in Venezuela is extremely significant because it is the only one for northern South America; the geographically nearest records are from Bolivia and Brazil (about $2700 \mathrm{~km}$ away). The entrance of the short-faced bears into South America is expected to be documented by future findings in the late Pliocene or early Pleistocene of this part of the continent (SoIBELzon et al. 2005). In addition, the Venezuelan record provides information about a poorly recorded taxon.

In this paper we review the taxonomy of the fossil bears from Venezuela, providing descriptions for both known and new fossil remains (including the first description of the I1-3 and p4 morphology in this species). The new fossil remains consist of three specimens from two localities (see below, chapter 3). It is noteworthy that these are the first records of A. wingei with accurate stratigraphic provenance. Although the record from Bolivia lacks unambiguous indications of its provenance, and those from Brazilian localities are out of stratigraphic context (see Soibelzon et al. 2005), we believe that $A$. wingei is restricted to the late Pleistocene, since it has never been recorded in the Ensenadan or Bonaerian, where more than 180 Arctotherium specimens have been recorded so far. In addition, we discuss the paleobiology of $A$. wingei and the paleobiogeographic implications of its northern records. 


\section{Material and methods}

In discussing dental morphology and systematics, we rely mostly on the nomenclature and characters used by SOIBELzON (2004); anatomical notation and orientation of dentition follow the terminology of SMITH \& Dodson (2003). Chronostratigraphic/ geochronologic units (Ensenadan, Bonaerian and Lujanian) follow the definitions of WOODBURNE et al. (2006). All measurements were taken with dial calipers. Fig. 4 shows a reconstruction of the past distribution of $A$. wingei and $A$. tarijense constructed by linking the localities where they were recorded (assuming that the species occurred in the encompassed area) over a map of South America. The map (taken from CIONE et al. 2003) also depicts biome distribution in South America during the last glacial maximum (see CiONE et al. 2003 for more details).

Specimens used for comparison: MACN 1453, type of Arctotherium wingei from Tarija Valley, Bolivia. UZM $5249,5715,5717,5721-22$, and 5723; types of Ursus brasiliense Lund from several caves in Lagoa Santa region, Brazil (see WINGE 1895-1896). Other specimens of $A$. wingei from Brazil: Minas Gerais state, Lapa da Escrivania N 5: MACN 6273; Ceará state, Ubajara: GP/2-T4 (out of stratigraphic context; see TRAJANO \& FERRAREZZI 1994); Bahía state, Campo Formoso: IGC 10 (out of stratigraphic context, see CARTELLE 1998). The specimens of $A$. tarijense, $A$. bonariense, $A$. vetustum and $A$. angustidens used for comparison are those listed in SOIBELZON (2004).

Abbreviations: IGC, Instituto de Geociências, Universidade Federal de Minas Gerais, Brazil; GP Instituto de Geociências, Universidade de Sao Paulo, Brazil; MACN, Museo Argentino de Ciencias Naturales "Bernardino Rivadavia”, República Argentina; MBLUZ, Museo de Biología de la Universidad del Zulia, Venezuela; VF, Museo Royo y Gómez, Universidad Central de Venezuela, Venezuela; UZM, Zoological Museum, University of Copenhagen, Denmark.

\section{Systematic paleontology}

Class Mammalia Linnaeus, 1758

Order Carnivora BowDICH, 1821

Family Ursidae GraY, 1825

Subfamily Tremarctinae MERRIAM \& STOCK, 1925

Genus Arctotherium BURMEISTER, 1879

Arctotherium wingei AMEgHINo, 1902

(Synonyms: Arctotherium cf. brasiliense RoYo y GoMEZ, 1960; Arctodus brasiliensis BoCQUENTIN-VILlANUEVA, 1979)

Fig. 2
Holotype: MACN 1453, from Tarija Valley, Bolivia; Pleistocene (AMEGHINO 1902).

Distribution: Bolivia, Brazil and Venezuela, late Pleistocene to early Holocene (for a discussion of the temporal distribution of $A$. wingei outside Venezuela see Sorbelzon 2004).

Referred specimens: VF-405 (left P4 and M1) and VF-406 (left M2) both numbers correspond to the same specimen (Fig. 2a); MBLUZ-P-5.117 (left portion of premaxilla with I1-3) (Fig. 2b); MBLUZ-P-5.122 (left p4), MBLUZ-P-5.119 (left m1), MBLUZ-P-5.120 (left m2) (Fig. 2c) the three numbers correspond to the same specimen; MBLUZ P-5.121 (right m1), MBLUZ-P-5.216 (right $\mathrm{m} 2$ ) both numbers correspond to the same specimen (Fig. 2e); MBLUZ-P-5.118 (left C1) (Fig. 2d).

Locality and age: VF-405 and VF-406 from Muaco paleontological site, located in northeastern Falcón State between the villages of Muaco and Carrizal (Fig.1); $(16.375 \pm 400$ and $9.030 \pm 240$ years BP, see BocQuetiNVillanueva 1979), late Pleistocene. MBLUZ-P-5.216 to P-5.122 from "Cueva del Guácharo" $\left(10^{\circ} 10^{\prime} 27 " \mathrm{~N}\right.$, $62^{\circ} 33^{\prime} 07^{\prime}$ 'W, Fig. 1), Monagas state. Morgan et al. (1988) established the age of the sediments as the period between late Pleistocene and early Holocene on the basis of the presence of Desmodus draculae and Diphylla ecaudata (Mammalia, Chiroptera); see "Paleoenvironment and Paleoecology" below.

Description and comparisons: The crown of the first incisor (I1) (MBLUZ-P-5.117, Fig. 2b) is proportionally low and laterally wide. The occlusal outline is triangular. Unfortunately the occlusal surface is badly worn, thus precluding a description of its morphology. The crown of the second incisor (I2) (MBLUZ-P-5.117, Fig. 2b) is proportionally high and laterally narrow, especially at the middle and basal portions of the tooth. The oclussal outline is subtriangular. The main cusp is rostro-caudally compressed and laterally expanded. The lingual shelf is subhorizontal, with two rounded ridges at the mesial and labial margins. The labial ridge is shorter and narrower than the mesial ridge. A minute enamel bulge is situated between these ridges and the main cusp. The third incisor I3 (MBLUZ-P-5.117, Fig. 2b) is the largest incisor of the upper series; it is caniniform, with high, laterally compressed crown. The main cusp is morphologically similar to that of the $\mathrm{I} 2$, the mesial ridge is wider and longer than the labial one and there is no enamel bulge between them. See Table 1 for comparisons of incisor morphology with other Arctotherium species.

The crown of the upper canine (MBLUZ-P-5.118, Fig. $2 \mathrm{~d}$ ) is distally curved, with apex disto-labially directed. Both the crown and the root are labio-lingually compressed. The lingual side has a thin enamel edge extending from the base to the crown apex. The distal side is convex, and the mesial side is slightly flattened. The basal margin of the crown at its mesial side descends sharply and then ascends forming a V-shaped notch. At the lowest point of this notch there is a protuberance with two enamel crests that diverge 

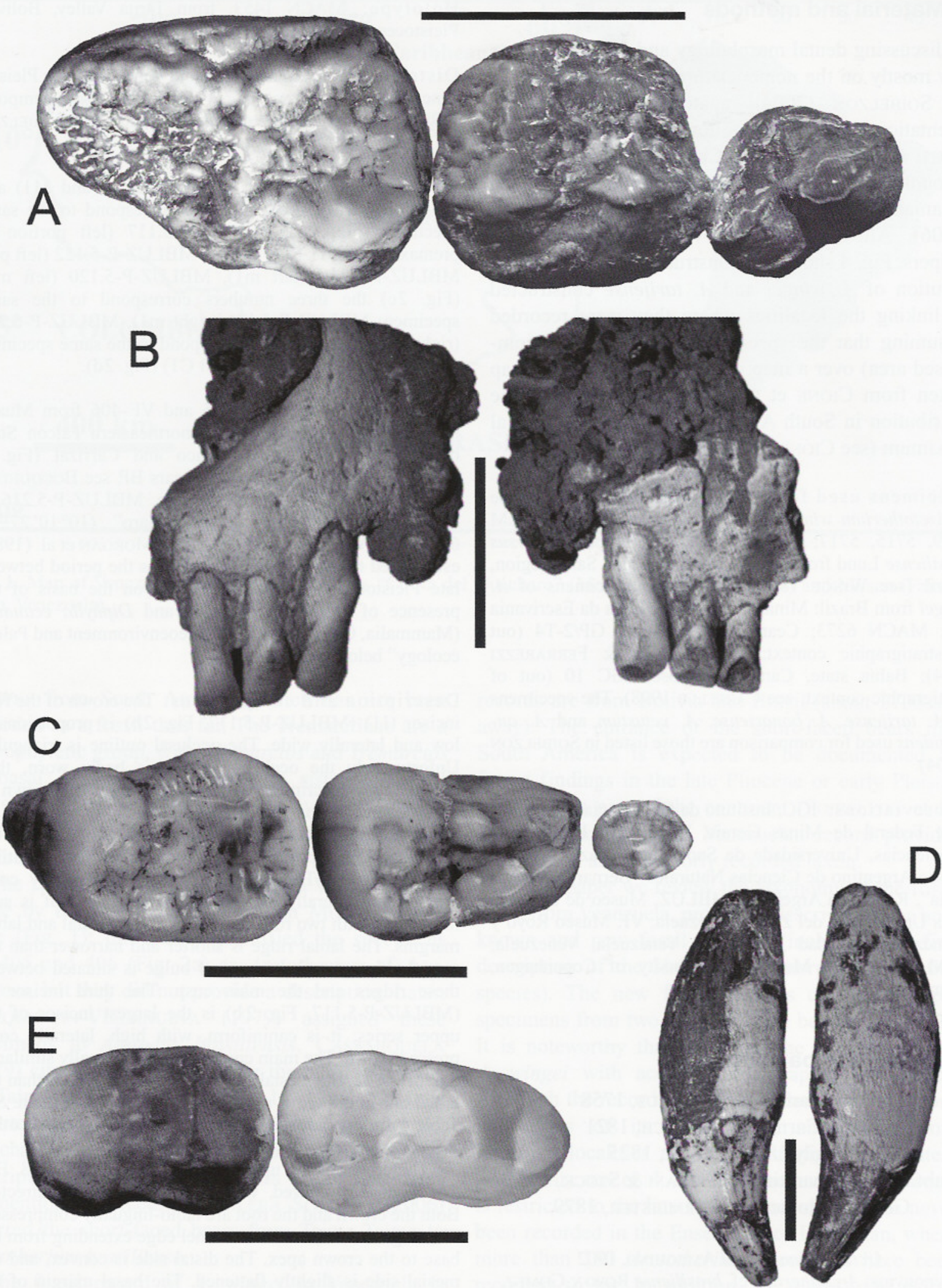

Fig. 2 (Legend see p. 291) 
obliquely, one descending toward the crown apex and the other rising toward the tooth base. MBLUZ-P-5.118 shows the same morphology as UZM 5717 (holotype of Ursus brasiliensis) but it is much more robust. The morphology of the canine tooth is similar among Arctotherium species (as well as in the entire subfamily Tremarctinae), and the taxa differ mainly in the size of this tooth.

The crown of the fourth upper premolar (P4) (VF-405, Fig. 2a) is subtriangular in occlusal view. The labial margin is almost straight and the lingual margin is very convex. The labial side of the crown is occupied by the paracone (largest cusp) and the metacone. Both cusps are laterally compressed, and connected by an enamel ridge that extends mesiodistally between their apices. The lingual side of paracone and metacone forms a flat vertical surface. A very small and rounded protocone can be seen on the lingual side of the crown. VF-405 is wider compared to UZM 5715 (Type of Ursus brasiliensis) because the lingual projection bearing the protocone is more developed, and the crown of UZM 5715 is much more laterally compressed. In this respect the morphology of GP/2-T4 is the same as that of the Venezuelan individual; these differences among specimens are normal and have been observed in other tremarctine taxa. See Table 2 for morphological comparison with the other Arctotherium species and Table 3 for size comparisons.

The crown of the first upper molar (M1) (VF-405, Fig. $2 a)$ is as wide as it is long. The labial margin is convex and longer than the lingual margin, which is very convex. The mesial and distal margins are almost straight and converge toward the lingual side. The occlusal outline of the crown is sub-quadrate. The two labial cusps are mesiodistally elongated, and both are much larger than the lingual cusps. The mesial cusp (paracone) is larger and slightly more compressed than the distal cusp (metacone). The paracone is lingually inclined, while the metacone is vertical. A small but well differentiated cusp, the parastyle, arises in front of the paracone, and the metastyle is absent. A deep furrow, with several enamel bulges on its surface, extends mesiodistally between the labial and lingual cusps. Four or five relatively low cusps are arranged in a mesiodistal series on the lingual margin of the crown. The first of the series is a small cusplet that lies at the mesio-lingual angle. This cusp forms a continuous crest with the larger central cusp (protocone). Two small cusps lie behind the protocone, in front of the metacone; the distal cusp is somewhat lower than the proximal one. No cingulum is observed, other than a slight widening of the enamel along the labial side of the metacone. The morphology of this specimen does not differ

\footnotetext{
Fig. 2. Fossil specimens of Arctotherium wingei from Venezuela. a - VF-405 (left P4 and M1) and VF-406 (left M2); b - MBLUZ-P-5.117 (left I1-3); c - MBLUZP-5.122 (left p4), MBLUZ-P-5.119 (left m1), MBLUZP-5.120 (left m2); d - MBLUZ-P-5.118 (left C1); e MBLUZ-P-5.121 (right m1), MBLUZ-P-5.216 (right m2). Scale bar equals $2 \mathrm{~cm}$.
}

significantly from other $A$. wingei specimens, except for a thin cingulum that crosses the labial side at half the height of the paracone and metacone; this cingulum is present in GP/2-T4 but not in UZM 5715. See Table 4 for morphological comparison with the other Arctotherium species and Table 3 for size comparisons.

The upper second molar (M2) (VF-406, Fig. 2a) exhibits the most complicated morphology of all molars. Both the labial and mesial sides are almost straight; the distal side is rounded and the labial side presents two lobes (corresponding to the paracone and metacone) followed distally by a concavity (corresponding to the talon area). The occlusal outline is subtriangular, with the labial and mesial (shortest) sides at right angles, and the labial (longest) side extending obliquely from the mesio-lingual corner to the distal end. Two large conical cusps lie on the labial border of the trigon area; the mesial and larger one is the paracone, and the distal one is the metacone. A small parastyle occurs at the mesial side of the paracone. A deep furrow extends mesio-distally between the labial and lingual cusps, as in the M1, but its surface is creased by a large number of enamel ridges and bulges. The cusps at the lingual border of the crown are small, low and rounded, forming a continuous mesio-distal series only interrupted by a shallow groove at the protocone-hypocone boundary. The mesialmost of the series is a small and laterally compressed cusplet (homologous to that described for the M1); it is followed by a larger rounded cusp, the protocone, situated in front of the paracone-metacone boundary. Behind the protocone, in the talon area, there is a ridge corresponding to the hypocone; this ridge becomes lower distally. VF-406 (as in GP/2-T4) presents a slim, horizontal and wrinkled surface on the lingual side of the ridge formed by a cusplet and the protocone (see above), while this surface is flat and subhorizontal in UZM 5723. See Table 5 for morphological comparisons with the other Arctotherium species and Table 3 for size comparisons.

The crown of the lower fourth premolar (p4) (MBLUZP-5.122, Fig. 2c) is oval in occlusal view. The main cusp (protoconid) is relatively low and occupies almost the entire crown; a very small cusplet lies at the distal side of the crown. See Table 6 for morphological comparisons with other Arctotherium species and Table 3 for size comparisons.

The crown of the lower first molar (m1) (MBLUZP-5.119, Fig. 2c, and MBLUZ-P-5.121, Fig. 2e) is subrectangular, with lingual margins almost straight, labial margin with two convexities (at the trigonid and talonid areas) and mesial and distal margins rounded. The trigonid bears three main cusps, i.e. paraconid, protoconid and metaconid, and an accessory cusp (always present in Tremarctinae) on the disto-labial side of the protoconid near its base. The paraconid lies on the mesial margin of the crown and is relatively smaller than the protoconid. The protoconid is the most conspicuous cusp; it occupies the entire width of the crown and completely separates the paraconid from the metaconid. The metaconid is smaller than the paraconid and lies on the lingual side of the crown just behind the protoconid. The talonid bears two main cusps, hypoconid and entoconid, separated from the protoconid and metaconid by a deep notch. The larger hypoconid is situated on the labial 


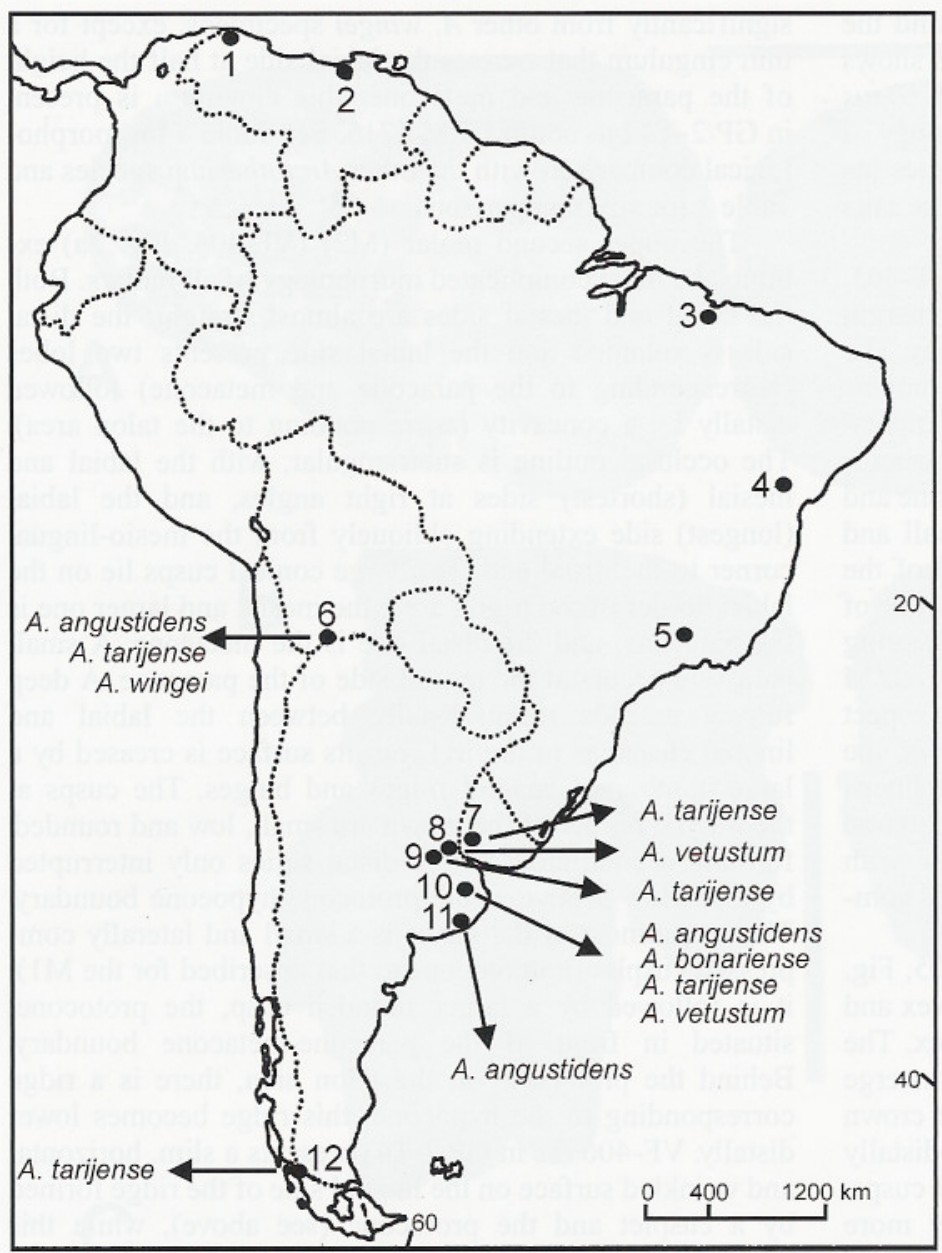

Fig. 3. Map of main South American localities for fossil tremarctines (modified from Solbelzon 2002a). 1. Falcón State, Venezuela. 2. Monagas State, Venezuela. 3. Ceará State, Brazil. 4. Bahía State, Brazil. 5. Minas Gerais State, Brazil. 6. Tarija valley, Bolivia. 7. Río Negro County, Uruguay. 8. Entre Ríos Province, Argentina. 9. Santa Fe Province, Argentina. 10. Coastal and central Buenos Aires Province, including Buenos Aires and La Plata Cities, Argentina. 11. Marine cliff in SE Buenos Aires Province, Argentina. 12 Pali Aike National Park and "Cueva del Milodon", Chile. Only Arctotherium wingei has been recorded in sites 1 to 5 . Modified from Soibelzon et al. (2005).

margin and formed by two cusps. The entoconid is relatively small, formed by two cusps, and situated on the lingual side of the talonid. The main difference between MBLUZ-P-5.119 and MBLUZ-P-5.121 is the robustness of the former (see Table 3), and the wear shown by the protoconid apex of the same specimen. Except for size, there are no remarkable differences between those specimens and others assigned to $A$. wingei. See Table 7 for morphological comparisons with other Arctotherium species and Table 3 for size comparisons.

The crown of the lower second molar (m2) (MBLUZP-5.120, Fig. 2c, and MBLUZ-P-5.216, Fig. 2d) is subrectangular to kidney-shaped. The mesial and distal margins are rounded, the lingual margin is almost straight and the labial margin shows two convex zones corresponding to the trigonid and the hypoconid. The talonid area is noticeably larger than the trigonid. A wrinkled mesio-distal valley splits the crown from mesial to distal margins, and is only interrupted by the great development of metaconid and protoconid. These two cusps occupy almost the entire trigonid area; they facing each other on opposite lateral sides of the crown, and their apices are connected by a conspicuous transversal enamel ridge. The paraconid is not present, even though some authors believe that it is represented by a small cusplet lying at the mesial margin of the crown (TORRES 1988). The larger cusp in the talonid area is the wide conical labial entoconid; the entoconid is represented by two laterally compressed cusps arranged in a mesio-distal line on the lingual margin of the crown. As in the $\mathrm{ml}$, there are no remarkable differences between these specimens and others assigned to $A$. winge $i$ except for size (see Table 3). See Table 8 for morphological comparisons with other Arctotherium species and Table 3 for size comparisons.

\section{Paleobiogeographic significance}

These new records fill an information vacuum in the fossil record of Tremarctinae bears in northern South America, while they allow to discuss the distribution of tremarctines in South America at the latest Pleistocene- early Holocene, just before the extinction of short-faced bears. Only two species are reliably recorded for this period, $A$. tarijense in southern South 
Fig. 4. Map of probable distribution of Arctotherium wingei (area 1) and A. tarijensis (area 2) during the Upper Pleistocene-Lower Holocene and the current distribution of Tremarctos ornatus (black, taken from CAVELIER et al., in press). The map also shows biome distribution in South America during the last interglacial maximum (taken from CiONE et al. 2003). The boundaries of vegetation areas are tentative. Cione et al. (2003) subdivided the vegetation types into 1) open areas (horizontal broken lines; Provincias Sabana, Desierto, Monte, Pampeana, Patagónica, Altoandina, Páramo, Puneña, Prepuneña, Guayana); mountains are included in this subdivision), 2) intermediate vegetated areas (right-to-left slanted lines; Provincias Caatinga, Chilena, Espinal, Cerrado, Chaqueña), and 3) forested areas (left-to-right slanted lines; Provincias Amazónica, Paranense, Yungas, Pacífica, Atlantica, Subantártica, Venezolana). Blank areas indicate areas above $2,000 \mathrm{~m}$ asl.

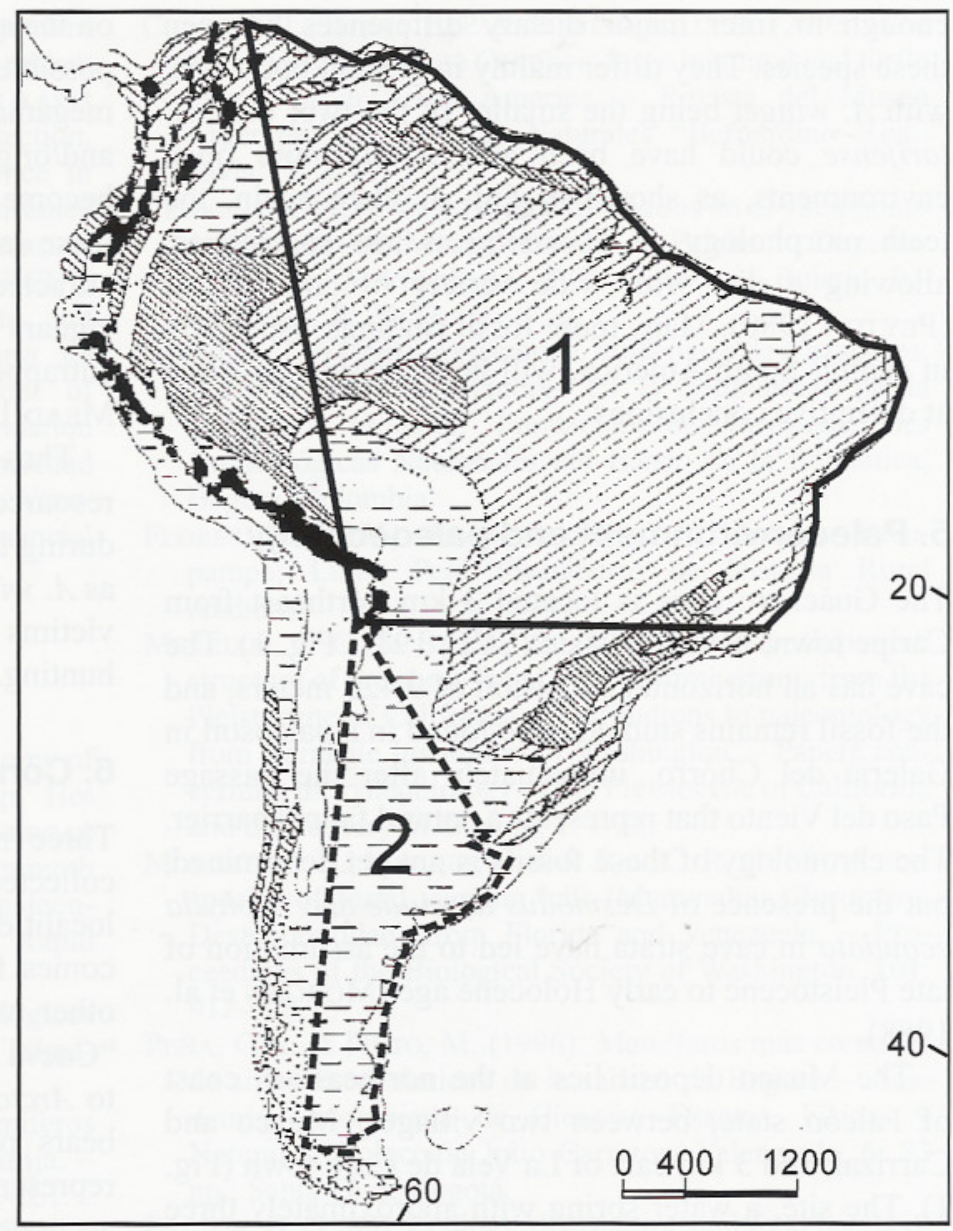

America, from Tarija to southern Chile, including Uruguay and Argentina (SoIBELzon et al. 2005) and A. wingei in northern South America, also from Tarija to Venezuela, including Brazil (Fig. 4). A third species could have occurred there at that time: Tremarctos ornatus, the spectacled bear, which has been recorded at 4030 and 2725 years BP in archaeological sites in Colombia (Correal 1990; Peña \& Pinto 1996) and at 1500 years BP in Perú (Flores 1975). Assuming that the geographical distribution of $T$. ornatus by the late Pleistocene was the same as its present-day range, we can envision these tree species occupying almost all of South America without overlapping, except for the Tarija valley (Fig. 4). T. ornatus inhabits the "Cordillera de los Andes" from Venezuela to Bolivia across Colombia, Ecuador and Perú, with a remarkable preference for highland forests (between 1800 and 3100 meters asl). On the other hand, the short-faced bears were adapted to open areas
(SoIBELzon 2002a) and were recorded in low lands. Tarija, the only locality where the distributions of these three species overlap, is located at 1860 meters asl, the lower boundary for the preferred altitude of $T$. ornatus and the highest locality recorded for $A$. wingei and $A$. tarijense. This particular situation could be related to the biomes existing in the area during that time (Fig. 4). Thus, we could speculate that A. tarijense was adapted to open areas (savannas, deserts, backwoods, grasslands, etc.) while A. wingei inhabited intermediate vegetated areas, and $T$. ornatus occupied the areas at $1800 \mathrm{~m}$ asl, which comprise a mix of forested and intermediate vegetated areas (CAVELIER et al., in press, and others). In addition, the $21^{\circ} \mathrm{S}$ parallel of latitude seems to represent a barrier for both the northern bears ( $A$. wingei and $T$. ornatus) and the southern species (A. tarijense). The paleobiology of $A$. wingei and $A$. tarijense is not known, but the differences in teeth morphology are not large 
enough to infer major dietary differences between these species. They differ mainly in general body size, with $A$. wingei being the smaller of the two; thus, $A$. tarijense could have been adapted to more open environments, as shown in Fig. 4. Then again, the teeth morphology of $T$. ornatus is less specialized, allowing a diet with wide variety of components (PEyton 1980). Many more fossil findings, especially in central South America, will be necessary to arrive at definitive conclusions.

\section{Paleoenvironment and paleoecology}

The Guácharo cave is located $3 \mathrm{~km}$ northeast from Caripe town, Monagas state (SVE, 1971; Fig. 1). The cave has an horizontal extension of 9.425 meters, and the fossil remains studied were found in a paleosoil in Galeria del Chorro, immediately after the passage Paso del Viento that represents a natural faunal barrier. The chronology of these fossils is not yet determined, but the presence of Desmodus draculae and Diphylla ecaudata in cave strata have led to the assumption of late Pleistocene to early Holocene age (MorGAN et al. 1988).

The Muaco deposit lies at the northeastern coast of Falcón state, between two villages, Muaco and Carrizal, and $3 \mathrm{~km}$ east of La Vela de Coro town (Fig. 1). The site, a water spring with approximately three meters deep of swamp sediments, has been radiocarbon dated at between 16,375 \pm 400 and 9,030 \pm 240 years BP, thus corresponding chronologically to late Pleistocene - early Holocene (BOCQUENTINVillanueVA 1979).

CRUXENT (1961) interpreted this fossil bed as a human overkill site; he identified several pierced megammal skulls and many bones whose apophyses showed signs of fire exposure. However, the faunal composition is trophically balanced, comprising typical Pleistocene megaherbivores such as Eremotherium laurilardi, Glossotherium tropicorum, Stegomastodon waringi, Glyptodon clavipes, Macrauchenia patachonica, Odocoileus peruviana, and Mixotoxodon larensis, and carnivores such as Puma concolor, Panthera onca, Canis dirus, and Conepatus semistriatus (BoCQUENTIN-VILlanUeVA 1979).

This type of faunal assemblage resembles the Hot Springs Mammoth site in South Dakota, United States of America (AGENBROAD \& MEAD 1994), because both contain large herbivorous mammals while carnivores are poorly represented; also, both sites are formed by a gypsiferous deposit, with water and grass on the surface (Bocquentin-VILLANUEVA 1979). It is possible that in Muaco, as in Hot Springs, the megamammals were attracted by the available water and/or grass to the vicinity of the water spring, only to become trapped and die on entering the pond. After these large herbivores died, their bodies could have attracted carnivores or opportunistic animals such as jaguars and dire wolves, which would also become entrapped in the waterhole and die (AGENBROAD \& MEAD 1994).

Thus, Muaco was one of the few sites with water resources available in the north coast of Falcon state during the late Pleistocene; a place that animals, such as $A$. wingei, visited in order to drink, only to become victims of waterhole entrapment rather than human hunting.

\section{Conclusions}

Three new fossil specimens of Tremarctinae bears collected in Lujanian sediments of two Venezuelan localities are described. One (VF-405 and VF-406) comes from the Muaco paleontological site and the other two (MBLUZ-P-5.216 to P-5.122) come from "Cueva del Guácharo". All of them are assigned here to Arctotherium wingei (similarly to the other fossil bears previously described from Venezuela). They represent the first specimens of this species with accurate stratigraphic provenance, since those from Bolivia lack stratigraphic information and those from Brasil were found out of stratigraphic context. In this respect, these new records support the Lujanian age invoked for the specimens collected in Brazilian caves (see Soibelzon et al. 2005).

The paleobiogeographic reconstruction presented here interprets the observed paleodistribution of $A$. winge $i$ and $A$. tarijense as differential environmental preferences, probably associated with the body size differences between these species. In this sense, the geographic distribution of $A$. wingei (the smallest South American fossil bear) could have been influenced by the less open environments occurring north of latitude $21^{\circ} \mathrm{S}$ by the end of the Pleistocene.

In addition, a brief discussion of the paleoenvironmental and paleoecological interpretation of the fossiliferous sites is provided.

\section{Acknowledgements}

The authors thank Ing. IMERU Alfonzo (Museo José Royo y Gómez) and Dr. Franco URBani, who donated the specimens from Cueva del Guácharo. Dr. EdUARDO P. 
TONNI and an anonymous reviewer provided important comments and corrections during the manuscript review process. Dr. Alejandro Kramarz (MACN) and Kim Aaris (UZM) for help with the collections under their protection. ROBERT H. RAINEY (chief preparator), for assistance in material casting, and Dr. ANGEL VILORIA for assistance in cleaning the Guácharo material. CECILIA Morgan improved the English. The authors also thank CONICET; Fundación Antorchas; AMNH Office of Grants and Fellowships; ANPCyT PICT 8395; and Secretaría de Ciencia y Técnica de la UNLP, Jackson School of Geosciences, University of Texas at Austin; Foundation for Quaternary Paleontology in Venezuela; Sociedad Venezolana de Espeleología (SVE), and Instituto Venezolano de Investigaciones Científicas (IVIC), for financial support.

\section{References}

Agenbroad, L. D. \& MeAd, J. I. (1994): The taphonomy of Mammuthus remains in a closed system trap, Hot Springs Mammoth site, South Dakota. - In: AGENBROAD L. D. \& MEAD, J. I. (Eds.): The Hot Springs Mammoth site: A decade of field and laboratory research in paleontology, geology and paleoecology, p. 283-305; Rapid City, South Dakota.

Aguilera Socorro, O. A. (2006): Tesoros paleontológicos de Venezuela: El Cuaternario del estado Falcón (TaimaTaima). - 120 pp.; Caracas (Editorial Arte).

AMEGHINO, F. (1902): Notas sobre algunos mamíferos fósiles nuevos o poco conocidos del valle de Tarija. Anales del Museo Nacional Buenos Aires, 3: 225-261.

BoCQUENTIN-VILLANUEVA, J. (1979): Mammifères fossiles du Pléistocène supérieur de Muaco, État de Falcón, Vénézuéla. - Unpublished Thesis, 1'Université Pierre et Marie Curie, Paris. - 112 pp.

Burmeister, H. (1879): Description physique de la Republique Argentine d' prés des observationes personalles et éntragéres. Tradult de 1' allemand avec le concourse de E. Daireaux. Tome troisième: Animax vertébrés. Premiére partie: Mammiféres vivants et éteints, 3, 556 pp.; Buenos Aires.

Cartelle, C. (1998). Um pequeño urso do Pleistoceno final da Bahia. - Acta Geológica Leopoldensia, 21: 171-189.

CAsamiquela, R. (1979): An interpretation of the fossil vertebrates of the Taima-Taima site. - In: OCHSENIUS C. \& GRUHN R. (Eds.): Taima-Taima, A late Pleistocene kill site in Northermost South America - Final reports of 1976 excavations CIPICS/South American Quaternary Documentation Program, p. 59-76; Coro (Univ. Francisco de Miranda).

Cavelier, J., Lizcano, D., Yerena, E. \& Downer, C. (in press): The mountain tapir (Tapirus pinchaque) and Andean bear (Tremarctos ornatus): the two large mammals in South American tropical montage cloud forests. - In: Bruijnzeel, L. A., Scatena, F. N., Hamilton, L. S. JuviK, J. \& BuBB, P. (Eds.): Proceedings of the $2^{\text {nd }}$ International Symposium on Tropical Montane Cloud Forests; Hawaii (University of Hawaii Press).
Cione, A. L, Tonni, E. P. \& Solbelzon, L. H. (2003): The broken Zig-Zag: Late Cenozoic large mammal and turtle extinction in South America. - Revista del Museo Argentino de Ciencias Naturales "Bernardino Rivadavia", 5: 1-19.

CRUXENT, J. M. (1961): Huesos quemados en el yacimiento prehistórico de Muaco. Estado de Falcón. - Departamento de Antropología, IVIC, Caracas, Boletín Informativo, 2: 20-21.

Correal, G. (1990): Aguazuque, evidencias de Cazadores, Recolectores y Plantadores en la Altiplanicie de la Cordillera Oriental. Fundación de Investigaciones Arqueológicas Nacionales del Banco de la República; Bogotá, Colombia.

FloRes, Y. (1975): Excavaciones en el Mirador: Pacopampa; Lima, Perú (Seminario de Historia Rural Andina).

Merriam, J. C. \& Stock, C. (1925): Relationships and structure of the short-faced bear, Arctotherium, from the Pleistocene of California. Contributions to paleontology from Carnegie Institution of Washington. - Papers concerning the paleontology of the Pleistocene of California and the Tertiary of Oregon, 1: 1-35.

Morgan, G. S., Linares, O. J. \& RaY, C. R. (1988): A new species of fossil vampire bats (Mammalia: Chiroptera: Desmodontidae) from Florida and Venezuela. - Proceedings of the Biological Society of Washington, 101: 912-928.

Peña, G.A. \& Pinto, M. (1996): Mamíferos más comunes de sitios Precerámicos de la sabana de Bogotá. - Academia Colombiana de Ciencias Exactas, Físicas y Naturales, Colección Julio Carrizosa Valenzuela, 6: 83 pp.; Santa Fé de Bogotá.

Peyton, B. (1980): Ecology, distribution and food habits of spectacled bears, Tremarctos ornatus, in Peru. - Journal of Mammalogy, 61: 639-652.

Royo y GómEZ, J. (1960): El yacimiento de vertebrados fósiles del pleistoceno superior de Muaco, estado Falcón, Venezuela, con industria lítica humana. - Report of the twenty - first semion orden. Part IV procedding of section 4. - Chronology and climatology of the Quaternary, 1: 154-157.

Smith, J. B., \& Dodson, P. (2003): A proposal for a standard terminology of anatomical notation and orientation in fossil vertebrate dentitions. - Journal of Vertebrate Paleontology, 23: 1-14.

Soibelzon, L. H. (2002a): Los Ursidae (Carnivora, Fissipedia) fosiles de la Republica Argentina. Aspectos sistematicos y paleoecologicos. - Unpublished Thesis, Universidad Nacional de La Plata. - 239 pp.

- (2002b): A General Review of the South American Pleistocene Short-Faced Bears (Ursidae: Tremarctinae). - Actas 14 $14^{\text {th }}$ International Congress on Bear Research and Management. Steinkjer, 1: 92.

- (2004): Revisión sistemática de los Tremarctinae (Carnivora, Ursidae) fósiles de América del Sur. - Revista del Museo Argentino de Ciencias Naturales, 6: 107-133.

Solbelzon, L. H., Tonn, E. P. \& Bond, M. (2005): The fossil record of South American short-faced bears (Ursidae, Tremarctinae). - Journal of South American Earth Sciences, 20: 105-113. 
Torres, T. (1988): Osos (Mammalia, Carnivora, Ursidae) del Pleistoceno de la Península Ibérica. - Publicación especial del Boletín Geológico y Minero, Instituto Geológico y Minero de España, 99: 1-316.

Trajano, E. \& Ferrarezzi, H. (1994): A fossil bear from northeastern Brazil, with a phylogenetic analysis of the South American extinct Tremarctinae (Ursidae). Journal of Vertebrate Paleontology, 14: 552-561.

WINGE, H. (1895-1896): Jordfundne og nulevende Rovdyr (Carnivora) fra Lagoa Santa, Minas Geraes, Brasilien. E. Museo Lundii, 2: 103 pp.

Woodburne, M. O., Cione, A. L. \& Tonni, E. P. (2006): Central American provincialism and the Great American Biotic Interchange. - In: CARRANZA-CASTAÑEDA, O. \& LINDSAY, E. H. (Eds.): Advances in late Tertiary vertebrate paleontology in Mexico and the Great American Biotic Interchange. - Universidad Nacional Autónoma de México, Instituto de Geología and Centro de Geociencias, Publicación Especial, 4: 73-101.
Manuscript received: December 7th, 2006.

Revised version accepted by the Stuttgart editor: March 27 th, 2007.

\section{Addresses of the authors:}

Sorbelzon, L. H., Departamento Palentología de Vertebrados, Museo de La Plata. CONICET. Paseo del Bosque, CP 1900, La Plata, Argentina;

e-mail: 1soibelzon@museo.fcnym.unlp.edu.ar

Rincón, A. D., Instituto Venezolano de Investigaciones Científicas (IVIC), Centro de Ecología, Laboratorio de Biología de Organismos, Carretera Panamericana, Km 11, Aptdo. 21827, Cod. Postal 1020-A, Caracas, Venezuela; e-mail: arincon@ivic.ve

\section{Appendix}

Table 1. Comparative morphology of upper incisors of Arctotherium species. 1. Relative size of distal ridge; 2 . Occurrence of enamel bulge between mesial and distal ridges; 3 . Relative size of mesial ridge.

\begin{tabular}{ccccc}
\cline { 2 - 5 } & A. wingei & A. vetustum & A. angustidens & A. tarijense \\
\hline 1 & very small & very small & small & large \\
& present & present & absent & present \\
\hline 1 & very small & very small & small & big \\
$\simeq 2$ & present & present & absent & present \\
\hline 1 & large & very small & large & large \\
$\simeq 3$ & large & small & large & large \\
\hline
\end{tabular}

Table 2. Comparative morphology of P4 of Arctotherium species. 1. Occurrence of linguo-distal cingulum; 2. Comparative height of paracone and metacone relative to each other; 3 . Occurrence and relative size of protocone; 4 . Orientation of surface formed by the lingual sides of paracone and metacone.

\begin{tabular}{|c|c|c|c|c|c|}
\hline & A. wingei & A. vetustum & A. angustidens & A. bonariense & A. tarijense \\
\hline 2 & \begin{tabular}{l}
\multicolumn{1}{c}{ absent } \\
paracone much \\
more higher \\
than metacone
\end{tabular} & $\begin{array}{l}\text { present } \\
\text { paracone higher } \\
\text { than metacone }\end{array}$ & $\begin{array}{l}\text { absent } \\
\text { paracone much } \\
\text { more higher } \\
\text { than metacone }\end{array}$ & \begin{tabular}{l}
\multicolumn{1}{c}{ absent } \\
paracone much \\
more higher \\
than metacone
\end{tabular} & \begin{tabular}{l}
\multicolumn{1}{c}{ absent } \\
paracone much \\
more higher \\
than metacone
\end{tabular} \\
\hline 3 & $\begin{array}{l}\text { present and } \\
\text { relatively small }\end{array}$ & $\begin{array}{l}\text { present and } \\
\text { relatively small }\end{array}$ & $\begin{array}{l}\text { present and } \\
\text { relatively big }\end{array}$ & absent & $\begin{array}{l}\text { variable } \\
\text { presence and } \\
\text { relatively small }\end{array}$ \\
\hline 4 & vertical & $\begin{array}{l}\text { slightly inclined } \\
\text { lingually }\end{array}$ & vertical & $\begin{array}{l}\text { slightly inclined } \\
\text { lingually }\end{array}$ & vertical \\
\hline
\end{tabular}


Table 3. Measurements (in $\mathrm{cm}$ ) of $\mathrm{P} 4-\mathrm{M} 2$ and $\mathrm{p} 4-\mathrm{m} 2$ series of "Cueva del Guácharo" (Monagas state, Venezuela) and Muaco (Falcón State, Venezuela) bears and additional specimens of A. wingei from localities in Brazil and Bolivia. Mean values for other Arctotherium species are provided for comparison. (L) greatest mesio-distal length; (W) greatest labiolingual width; (1) data taken from Trajano \& Ferrarezzi (1994); (2) data taken from CARTELle (1998).

VF 504

VF 406

MBLUZP-5.119

MBLUZP-5.120

MBLUZP-5.121

MBLUZP-5.122

MBLUZP-5.216

MACN 1453

UZM 5715

UZM 5721

UZM 5722

UZM 5723

UZM 5249

MACN 6273

GP-2T4 (1)

MHN1 (1)

ICG-10 (2)

A. vetustum

A. tarijense

A. bonariense

A. angustidens

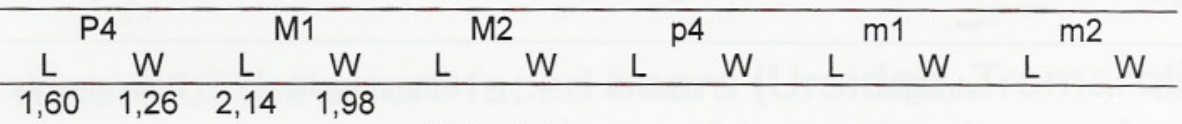

$3,10 \quad 2,12$

\begin{tabular}{|c|c|c|c|c|c|c|c|c|c|c|c|}
\hline & & & & & & & & 2,06 & 1,38 & & \\
\hline & & & & & & 0,77 & 0,66 & 2,27 & 1,32 & & \\
\hline 83 & 1.27 & 2,24 & 2,1 & & & & & 2,72 & 1,55 & $\begin{array}{c}1,90 \\
2,4\end{array}$ & $\begin{array}{c}1,35 \\
1,7\end{array}$ \\
\hline & & & & & & & & 2,8 & 1,4 & & \\
\hline & & & & 2.97 & 2 & & & & & 2,4 & 1,66 \\
\hline & & & & & & & & 2,36 & $\begin{array}{c}1,42 \\
1,2\end{array}$ & 2,1 & 1,65 \\
\hline $\begin{array}{l}1,42 \\
1,84\end{array}$ & $\begin{array}{l}1,04 \\
133\end{array}$ & $\begin{array}{l}2,10 \\
232\end{array}$ & $\begin{array}{l}1,97 \\
2,22\end{array}$ & $\begin{array}{l}2,64 \\
3,07\end{array}$ & $\begin{array}{l}1,96 \\
224\end{array}$ & 0,82 & 0,61 & 2,46 & 1,40 & 2,20 & 1,61 \\
\hline & & & & & & 1 & 0,5 & 2,4 & 1,2 & 2,1 & 1,5 \\
\hline 2 & 1,65 & 2,5 & 2,5 & 3,62 & 2,7 & 1,25 & 1,05 & 3,01 & 1,83 & 2,61 & 2,1 \\
\hline 31 & 1,9 & 2,69 & 2,98 & 3,65 & 2,87 & 1,5 & 1,2 & 3,54 & 2,12 & 3 & 2,21 \\
\hline & 2,1 & 3,1 & 3,3 & 4,03 & 3 & 1,47 & 1,2 & 3,96 & 2,32 & 3,13 & 2,54 \\
\hline 09 & 2,1 & 3,01 & 3.41 & 4.39 & 3.10 & 1,65 & 1,5 & 3,98 & 2,51 & 3,44 & 2,63 \\
\hline
\end{tabular}

Table 4. Comparative morphology of M1 of Arctotherium species. 1. Crown shape in occlusal view; 2.: Occlusal outline of lingual margin; 3. Comparative height of paracone and metacone relative to each other; 4 . Relative size of the parastyle; 5. Height and position of protocone and hypocone, and differentiation between them; 6 . Differentiation of a cusplet at the meso-labial angle of the protocone base; 7. Protocone morphology.

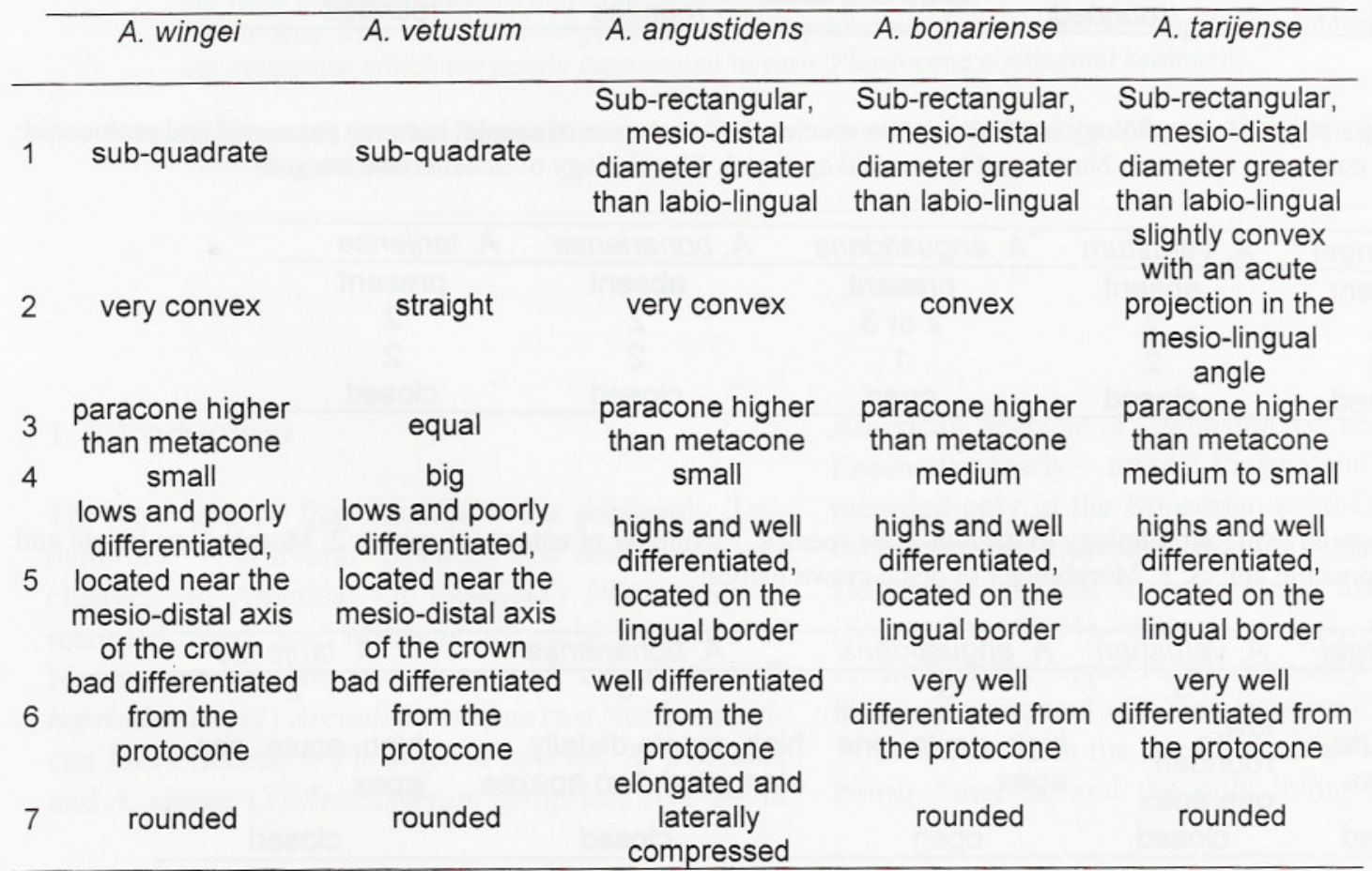


Table 5. Comparative morphology of M2 of Arctotherium species. 1. Occlusal outline of mesial margin of the crown; 2. Morphology of mesio-lingual angle of the crown; 3. Relative size of parastyle; 4. Height, arrangement and differentiation of trigon lingual cusps; 5. Morphology and number of hypocone apices; 6. Morphology of trigon and talon.

\begin{tabular}{|c|c|c|c|c|c|}
\hline & A. wingei & A. vetustum & A. angustidens & A. bonariense & A. tarijense \\
\hline 1 & straight & straight & convex & Sub-straight & Sub- straight \\
\hline & $\begin{array}{l}\text { small and } \\
\text { rounded }\end{array}$ & $\begin{array}{l}\text { large conforming } \\
\text { an acute shelf }\end{array}$ & $\begin{array}{l}\text { small and } \\
\text { rounded }\end{array}$ & $\begin{array}{l}\text { large conforming } \\
\text { an acute shelf }\end{array}$ & $\begin{array}{l}\text { large conforming } \\
\text { an acute shelf }\end{array}$ \\
\hline 3 & small & large & small & small & small \\
\hline & $\begin{array}{l}\text { conforming a low } \\
\text { and continuous } \\
\text { ridge without } \\
\text { differentiation }\end{array}$ & $\begin{array}{l}\text { conforming a low } \\
\text { and continuous } \\
\text { ridge without } \\
\text { differentiation }\end{array}$ & $\begin{array}{l}\text { conforming a high } \\
\text { and continuous } \\
\text { ridge, but better } \\
\text { differentiated }\end{array}$ & $\begin{array}{l}\text { conforming a high } \\
\text { and continuous } \\
\text { ridge, not well } \\
\text { differentiated }\end{array}$ & $\begin{array}{l}\text { conforming a high } \\
\text { and continuous } \\
\text { ridge, not well } \\
\text { differentiated }\end{array}$ \\
\hline 5 & $\begin{array}{l}\text { one apex } \\
\text { elongated in } \\
\text { mesio-lingual } \\
\text { direction }\end{array}$ & $\begin{array}{l}\text { one apex } \\
\text { elongated in } \\
\text { mesio-lingual } \\
\text { direction }\end{array}$ & $\begin{array}{l}\text { two apex, the } \\
\text { mesial one bigger } \\
\text { than the distal }\end{array}$ & $?$ & $\begin{array}{l}\text { two apex, the } \\
\text { mesial one bigger } \\
\text { than the distal }\end{array}$ \\
\hline & $\begin{array}{l}\text { conforming a } \\
\text { single } \\
\text { masticatory } \\
\text { surface }\end{array}$ & $\begin{array}{l}\text { conforming a } \\
\text { single } \\
\text { masticatory } \\
\text { surface }\end{array}$ & $\begin{array}{l}\text { well divided one } \\
\text { from each other } \\
\text { by a high labio- } \\
\text { lingual ridge }\end{array}$ & $\begin{array}{l}\text { well divided one } \\
\text { from each other } \\
\text { by a high labio- } \\
\text { lingual ridge }\end{array}$ & $\begin{array}{l}\text { well divided one } \\
\text { from each other } \\
\text { by a high labio- } \\
\text { lingual ridge }\end{array}$ \\
\hline
\end{tabular}

Table 6. Comparative morphology of p4 of Arctotherium species. 1. Crown shape in occlusal view; 2. Protoconid height and morphology; 3. Relative size and morphology of the distal cusplet.

\begin{tabular}{|c|c|c|c|c|}
\hline A. wingei & A. vetustum & A. angustidens & A. bonariense & A. tarijense \\
\hline 1 wide ellipsoid & wide ellipsoid & $\begin{array}{l}\text { wide ellipsoid to } \\
\text { circle }\end{array}$ & Sub-circle & wide ellipsoid \\
\hline 2 low and rounded & low and rounded & high and acute & low and rounded & $\begin{array}{l}\text { high and acute or } \\
\text { rounded }\end{array}$ \\
\hline $3 \begin{array}{l}\text { small and } \\
\text { rounded }\end{array}$ & $\begin{array}{l}\text { small and } \\
\text { rounded }\end{array}$ & large and acute & $\begin{array}{l}\text { very small and } \\
\text { rounded }\end{array}$ & $\begin{array}{l}\text { large and } \\
\text { rounded }\end{array}$ \\
\hline
\end{tabular}

Table 7. Comparative $\mathrm{m} 1$ morphology in Arctotherium species. 1. Occurrence of cusplet between paraconid and protoconid; 2. Number of entoconid apices; 3. Number of hypoconid apices; 4. Morphology of distal crown margin.

\begin{tabular}{cccccc}
\hline & A. wingei & A. vetustum & A. angustidens & A. bonariense & A. tarijense \\
\hline 1 & absent & absent & present & absent & present \\
2 & 2 & 2 & 2 or 3 & 2 & 2 \\
3 & 2 & 2 & 1 & 2 & 2 \\
& closed & closed & open & closed & closed \\
\hline
\end{tabular}

Table 8. Comparative m2 morphology in Arctotherium species. 1. Number of entoconid apices; 2. Morphology, height and number of hypoconid apices; 3 . Morphology of distal crown margin.

\begin{tabular}{|c|c|c|c|c|c|}
\hline & A. wingei & A. vetustum & A. angustidens & A. bonariense & A. tarijense \\
\hline 1 & 2 & 3 & 3 & 3 & 2 \\
\hline 2 & $\begin{array}{l}\text { low, acute, } \\
\text { one apex }\end{array}$ & $\begin{array}{l}\text { low, } \\
\text { rounded, } \\
\text { one apex }\end{array}$ & $\begin{array}{l}\text { high, acute, one } \\
\text { apex }\end{array}$ & $\begin{array}{l}\text { high, mesio-distally } \\
\text { elongated, two apexes }\end{array}$ & $\begin{array}{l}\text { high, acute, one } \\
\text { apex }\end{array}$ \\
\hline 3 & closed & closed & open & closed & closed \\
\hline
\end{tabular}

